\title{
A Message from the President
}

by E. Manley Callin, Fort San, Sask.

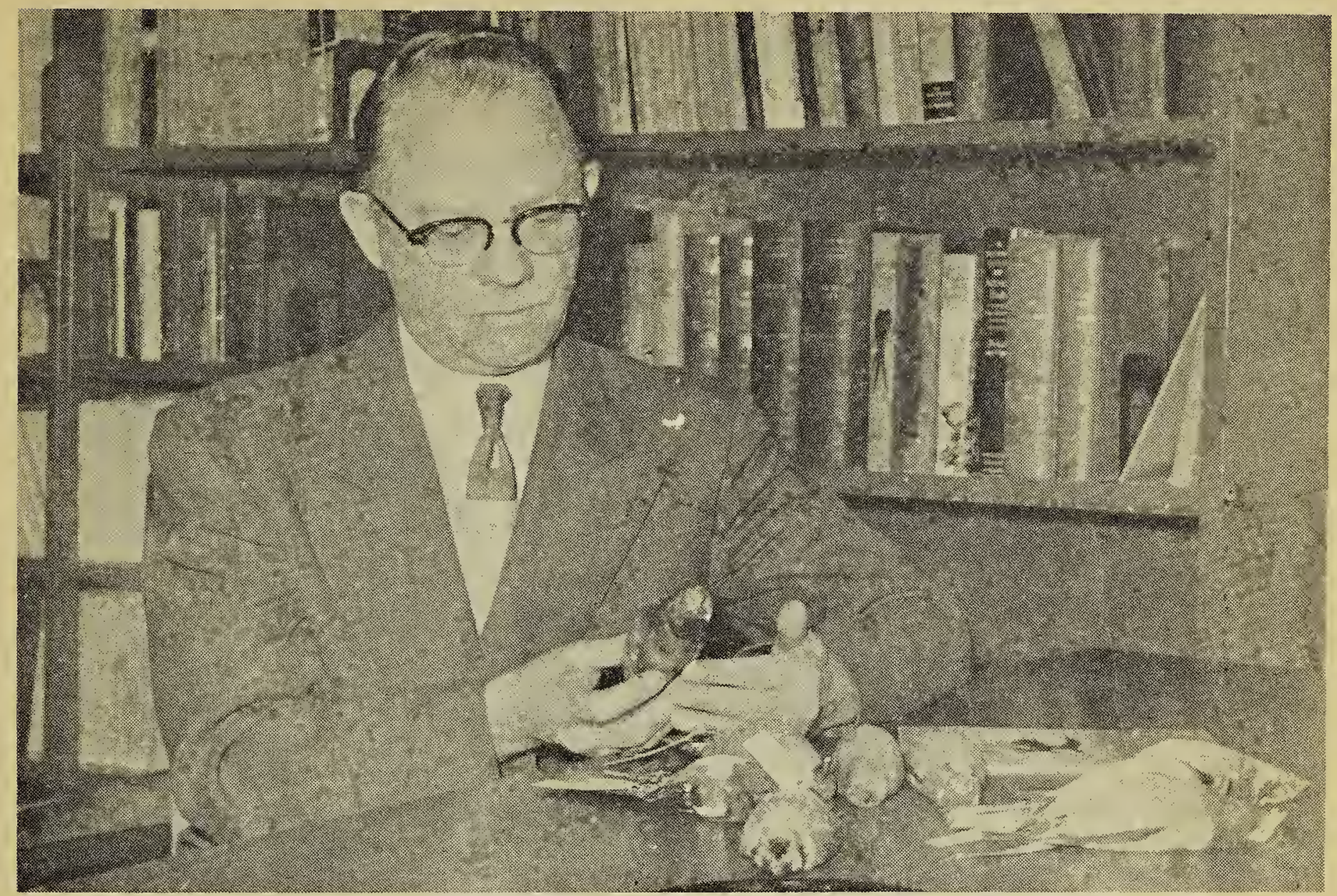

E. M. Callin, President, S: skatchewan Natural History Society

On behalf of the Saskatchewan Natural History Society, I take great pleasure in extending a warm and hearty welcome to all those who are attending the A.O.U. convention in Regina. Some of you are from other parts of Canada and some of you are neighbours from the south. Wherever your home, our doors are open and we hope that you will feél at home in Saskatchewan. May your stay be most pleasant. We have much in common with our sister provinces and with our great neighbour to the south and appreciation of our precious wildlife heritage is yet another area of common ground. Through the miracle of migration, mother nature even makes it possible for us in the north to enjoy the very same birds that you enjoy in the south.

We feel greatly honoured that Saskatchewan has been chosen as the site of this corvention. May we be excused in humbly accepting this as some measure of recognition of Saskatchewan's interest and progress in the field of natural history. It will most certainly provide us with additional inspiration and incentive for further progress.

EDITOR'S NOTE: Mr. Callin is in the process of preparing a check-list of the bircs of the Qu'Appelle Valley, based on personal observations recorded over a period of 32 years in that area.

\section{The American Ornithologists' Union}

The Am e ri c a n Ornithologists' Union, founded in 1883 , is the leading ornithological organization in the Western Hemisphere. Its aim - the a d vancemient of ornithological science - is effected through the programmes of its annual meetings (held in various parts of the United States and Canada), its publications, and the activities of its committees and members.

The Union publishes a quarterly journal, The Auk, received without charge by all members. Each issue contains major articles on birds, shorter general notes, reviews of new books, and a survey of recent periodical literature. At intervals, a com- 